\title{
Evaluation of Professional Personality Competence of Physical Education Teachers Working in Secondary Schools by Students
}

\author{
Erdal Demir \\ Correspondence: Erdal Demir, School of Physical Education and Sport, Çanakkale Onsekiz Mart University, Terzioğlu \\ Campus, 17100, Çanakkale, Turkey
}

\author{
Received: October 8, 2015 Accepted: October 23, 2015 Online Published: October 28, 2015 \\ doi:10.11114/jets.v4i2.1116 URL: http://dx.doi.org/10.11114/jets.v4i2.1116
}

\begin{abstract}
The aim of this article is to assess how students evaluate the professional personality competence of physical education teachers working in secondary schools, and to investigate differences based on the variables of gender, school type and class. In line with these aims, this study was completed as a screening model cross-sectional study, which was carried out in a total of 19 schools (16 state and 3 private) connected to the Ministry of National Education in Çanakkale, Turkey, in which 1421 secondary school students were enrolled during the 2013-2014 academic year. Of the research group $51.2 \%$ of the students were female and $48.8 \%$ were male. The data collection instrument was the PET PPCS-Student (Physical Education Teacher Professional Personality Competence Scale-Student), with which participants rate the professional personality competences of PETs (Physical Education Teachers). The T-test, ANOVA and Mann Whitney U-test were performed, and the results are presented here as descriptive statistics of frequency and percentage distributions. The lowest average score was for the "respect for human dignity and justice" subcomponent, being evaluated as "partly adequate." A significant difference was found between students of different school types and class backgrounds in their evaluations of PETs' professional personality competence.
\end{abstract}

Keywords: secondary school, physical education, physical education teacher, competence, professional personality competence

\section{Introduction}

The concept of competence is used to connote the notion of quality, or of meeting a standard. The concept of teacher competence incorporates the attitudes, knowledge and skills teachers should have. Competencies refer to the technical details of teachers' jobs (Turk Eğitim Derneği [TED], 2009).

Physical education can be an integral part of formal education and training. It can significantly contribute to students' cognitive, affective, social and psychomotor developments. Physical fitness improves leadership skills, self confidence, eating habits, classroom conduct, and love and respect for oneself and one's environment (Çamlıca, 2008). Physical education classes are also considered an enjoyable and generally positive experience by students (Güllü, Güçlü, \& Arslan, 2009; Şişko \& Demirhan, 2002; Tannehil \& Zakrajsek, 1993).

In education, one of the many variables affecting student success is the teacher (Centra \& Potter, 1980), who should not only teach the necessary curriculum but should also help students cultivate a love for physical activity (Eken, 2008). Teachers are responsible for improving the quality of teaching (Lee, Robinson \& Sebastian, 2012), as there is a positive correlation between teacher quality and student success (Darling-Hammond, 1999; Monk, 1994). Professional competence in personality-driven areas should therefore be considered a basic qualification for physical education teachers; if so, it will be possible to achieve more (Demirhan, Coşkun, \& Altay, 2002).

There are six general components to teacher quality: valuing students, respect for students' individual personalities and equality, social interaction, professional enthusiasm and motivation, positive job attitude and reflective interaction (Stronge, 2007). Ünlü, Sünbül and Aydos (2008) have added that knowledge, understanding, skill and a positive attitude are necessary in order for physical education teachers to competently perform the duties and responsibilities required of them. Büyüknacar (2008) also argued that physical education teachers' professional personality competence is a fundamental professional qualification for the field, and that it should be expected and evaluated as such.

The overall quality of physical education can be measured by evaluating 10 factors: the teachers, students, program, leadership, community, learning style, pedagogical style, lifetime learning ideals, research and assessment (Pill, 2004). 
The professional competencies of physical education teachers in these areas are very important in order to improve quality standards in physical education (Atencio, Jess, \& Dewar, 2012). According to Yaylac1 (2012), "Quality physical education lesson=Quality physical education teacher". Physical education teachers who are perceived as highly competent are those who exhibit positive classroom management behaviour (Ünlü, 2008).

The necessary competencies for physical education and sports teachers are: knowledge of the subject area, familiarity with scientific and philosophical basics, organizational and communication skills, willingness, respect in relationships, professional integrity and ethics, motivation, ability to understand individual students' development potential and curriculum planning skill (McNeil, 1985). According to research Saçlı et al, (2009) the most significant competency is openness to criticism, followed by ability to understand students, having a broad perspective, patience, self-confidence, the ability to improvise, creativity and compassion.

The purpose of this study is to examine the professional personality competence of physical education teachers in secondary schools as evaluated by students, and to investigate differences based on the variables of gender, school type and class. In this context, answers to the following questions were sought:

a) How do the professional personality competence of physical education teachers of working in secondary schools evaluate by students?

b) Was there the professional personality competence of physical education teachers of working in secondary schools different according to gender of students?

c) Was there the professional personality competence of physical education teachers of working in secondary schools different according to school type of students?

d) Was there the professional personality competence of physical education teachers of working in secondary schools different according to class of students?

\section{Method}

2.1 Research Design

This study examines the current situation in physical education using a screening cross-sectional model, a descriptive research method. Cross-sectional research using a screening model is compatable with research on any event within a certain timeframe (Karasar, 2011). In this study, the professional personality competence of physical education teachers was evaluated relative to the gender, school type and class of participating secondary school students.

Ethics committee permission for the research was obtained from the Çanakkale Onsekiz Mart University Health Sciences Institute Clinical Research Ethics Committee. Additional permissions were obtained from the Çanakkale Department of the Ministry of National Education.

\subsection{Participants}

The universe of this research included students enrolled in public and private secondary schools connected to the Ministry of National Education in Çanakkale. In the 2013-2014 academic year 21355 students from 95 public and 3 private secondary schools (totalling 98 schools) constituted the sampling population.

The sampling group was determined by the cluster method, a random selection method. Among the schools in the city of Çanakkale and its surrounding districts (Ayvacık, Bayramiç, Biga, Çan, Gelibolu, Gökceada, Ezine, Lapseki, Yenice), 19 (16 public, 3 private) secondary schools were selected from the 98 for participation. Fifth grade students were excluded from the research sample. Students were chosen randomly from among the sixth, seventh and eighth grade classes to achieve a total sample of 1421 students.

Of the participanting students, $48.8 \%(\mathrm{n}=693)$ were female and $51.2 \%(\mathrm{n}=728)$ were male. $33.6 \%(\mathrm{n}=478)$ of the research group consisted of sixth graders, 33.2\% $(\mathrm{n}=471)$ seventh graders and $33.2 \%(\mathrm{n}=472)$ eighth graders. $80.8 \%$ $(\mathrm{n}=1148)$ were enrolled at public schools and $19.2 \%(\mathrm{n}=273)$ at private schools.

\subsection{Data Collection Tool}

To evaluate the professional personality competencies of their physical education teachers, secondary school students were administered the Physical Education Teacher Professional Personality Competence Scale-Students (PET PPCS-Student). The PET PPCS-Student is based on the Professional Personality Scale developed by Büyüknacar (2008) and updated by adaptation for physical education teachers by Demir (2012). It consists of four subcomponents and 60 items. The four subcomponents are: Professional enthusiasm and dedication, Respect for human dignity and justice, Motivational interaction, and Reflective interaction. A five-point Likert scale was used, wherein students responded to survey items with: $1=$ Strongly disagree, $2=$ Disagree, $3=$ Neutral, $4=$ Agree, and $5=$ Strongly agree. The value ranges of the scale were rated as: $1-1.99=$ Completely inadequate, $2-2.99=$ Partly inadequate, $3-3.99=$ Partly adequate and $4-$ 
5=Completely adequate. The gender, class, and school type of participating students were also factored into the scale.

The overall reliability coefficient (Cronbach's alpha) of the scale is 0.98 , which falls into the category of high reliability.

\subsection{Data Analysis}

The data obtained were uploaded to a computer environment and descriptive statistics (mean and standard deviation) were calculated. SPSS package was used to analyze the data. For data with normal distribution the T-test and ANOVA test were used for parametric data analysis, while for data with non-normal distribution the Mann Whitney U-test was used for non-parametric data analysis. The significance level was accepted as 0.05 .

\section{Results}

Table 1. Descriptive Statistics of Scale Items

\begin{tabular}{lccc}
\hline Scale Items & $\mathrm{n}$ & $\overline{\mathrm{X}}$ & $\mathrm{SD}$ \\
\hline 2. She/he cares that honesty and trust form the basis of our communication at school & 1421 & 4.32 & 1.011 \\
5. She/he does not criticize a student who exhibits negative behaviour in front of the class & 1421 & 3.35 & 1.398 \\
\hline
\end{tabular}

The PET-PPSC-Student items with the highest and lowest average points are shown on Table 1. The highest average points $(\overline{\mathbf{X}}=4.32)$ were for the item "She/he cares that honesty and trust form the basis of our communication at school". This item was evaluated as "completely adequate" by the study group. The item with the lowest average points $(\overline{\mathbf{X}}=3.35)$ was "She/he does not criticize a student who exhibits negative behaviour in front of the class". This item of the scale was evaluated as "partly adequate" by the study group.

Table 2. Descriptive Statistics Belonging to Scale Factors

\begin{tabular}{lccc}
\hline Scale Factors & $\mathrm{n}$ & $\overline{\mathrm{X}}$ & $\mathrm{SD}$ \\
\hline Motivational interaction & 1421 & 3.99 & .969 \\
Professional enthusiasm and dedication & 1421 & 4.02 & .923 \\
Respect for human dignity and justice & 1421 & 3.79 & .942 \\
Reflective interaction & 1421 & 3.93 & .974 \\
\hline
\end{tabular}

After assessing the subcomponents of the PET-PPSC-Student, the category of "professional enthusiasm and dedication" received the highest average points $(\overline{\mathrm{X}}=4.02)$. It was evaluated as "completely adequate". The "respect for human dignity and justice" subcomponent had the lowest average points $(\overline{\mathrm{X}}=3.79)$ and was evaluated as "partly adequate". The "reflective interaction" ( $\overline{\mathrm{X}}=3.93)$ and "motivational interaction" $(\overline{\mathrm{X}}=3.99)$ subcomponents were also evaluated as "partly adequate" by the study group.

Table 3. Independent Group T-test of Factor Points by Gender

\begin{tabular}{llccccc}
\hline Scale Factors & Gender & $\mathrm{n}$ & $\overline{\mathrm{X}}$ & $\mathrm{SD}$ & $\mathrm{t}$ & $\mathrm{p}$ \\
\hline \multirow{2}{*}{ Motivational interaction } & Female & 693 & 4.04 & .950 & \multirow{2}{*}{2.265} & \multirow{2}{*}{$.024^{*}$} \\
& Male & 728 & 3.93 & .985 & & \\
Professional enthusiasm and dedication & Female & 693 & 4.07 & .917 & \multirow{2}{*}{1.845} & .065 \\
& Male & 728 & 3.98 & .927 & & \\
\multirow{2}{*}{ Respect for human dignity and justice } & Female & 693 & 3.83 & .932 & \multirow{2}{*}{1.331} & .183 \\
& Male & 728 & 3.76 & .951 & & \\
Reflective interaction & Female & 693 & 3.97 & .955 & \multirow{2}{*}{1.797} & .073 \\
\hline
\end{tabular}

$* \mathrm{p}<0.05$

A significant difference was found between the responses of male and female students on the motivational interaction subcomponent $(\mathrm{p}<0.05)$, but no significant difference was detected for the subcomponents of professional enthusiasm and dedication, respect for human dignity and justice, or reflective interaction ( $p>0.05)$. Male students evaluated their physical education teachers as "partly adequate" in all subcomponents. Female students evaluated the "respect for human dignity and justice" and "reflective interaction" subcomponents as "partly adequate," and the other two subcomponents as "completely adequate." 
Table 4. ANOVA Test of Factor Points by Class

\begin{tabular}{|c|c|c|c|c|c|c|}
\hline Scale Factors & Class & $\mathrm{n}$ & $\overline{\mathrm{X}}$ & SD & $\mathrm{F}$ & $\mathrm{p}$ \\
\hline \multirow{4}{*}{ Motivational interaction } & $6^{\text {th }}$ grade & 478 & 3.90 & 1.056 & \multirow[b]{3}{*}{10.086} & \multirow{4}{*}{$.000 *$} \\
\hline & $7^{\text {th }}$ grade & 471 & 4.15 & .850 & & \\
\hline & $8^{\text {th }}$ grade & 472 & 3.91 & .971 & & \\
\hline & Total & 1421 & 3.99 & .969 & \multirow{5}{*}{9.017} & \\
\hline \multirow{4}{*}{ Professional enthusiasm and dedication } & $6^{\text {th }}$ grade & 478 & 3.96 & .983 & & \multirow{4}{*}{$.000 *$} \\
\hline & $7^{\text {th }}$ grade & 471 & 4.17 & .807 & & \\
\hline & $8^{\text {th }}$ grade & 472 & 3.93 & .952 & & \\
\hline & Total & 1421 & 4.02 & .923 & & \\
\hline \multirow{5}{*}{ Respect for human dignity and justice } & $6^{\text {th }}$ grade & 478 & 3.73 & .967 & \multirow{5}{*}{11.470} & \multirow{5}{*}{$.000 *$} \\
\hline & $7^{\text {th }}$ grade & 471 & 3.96 & .845 & & \\
\hline & $8^{\text {th }}$ grade & 472 & 3.69 & .986 & & \\
\hline & Total & 1421 & 3.79 & .942 & & \\
\hline & $6^{\text {th }}$ grade & 478 & 3.82 & 1.039 & & \\
\hline \multirow{3}{*}{ Reflective interaction } & $7^{\text {th }}$ grade & 471 & 4.10 & 868 & \multirow{3}{*}{11.007} & \multirow{3}{*}{$.000 *$} \\
\hline & $8^{\text {th }}$ grade & 472 & 3.87 & 986 & & \\
\hline & Total & 1421 & 3.93 & 974 & & \\
\hline
\end{tabular}

$* \mathrm{p}<0.05$

When the results of the analysis were distributed by class, significant differences were found between sixth, seventh and eighth graders in all subcomponents $(\mathrm{p}<0.05)$. The sixth and eighth graders evaluated the professional personality competence of their physical education teachers "partly adequate". The seventh graders evaluated "respect for human dignity and justice" as "partly adequate" while rating the other three subcomponents as "completely adequate".

Table 5. Mann Whitney U-Test Results by subcomponent for the PET PPSC-Student by School Type

\begin{tabular}{llccccc}
\hline Scale Factors & School Type & $\mathrm{n}$ & Mean Rank & Sum of Rank & $\mathrm{Z}$ & $\mathrm{p}$ \\
\hline \multirow{2}{*}{ Motivational Interaction } & Public & 1148 & 679.66 & 780245.5 & -5.914 & $.000^{*}$ \\
& Private & 273 & 842.80 & 230085.5 & & \\
\multirow{2}{*}{ Professional enthusiasm and dedication } & Public & 1148 & 682.26 & 783239.5 & -5.418 & $.000^{*}$ \\
& Private & 273 & 831.84 & 227091.5 & & \\
\multirow{2}{*}{ Respect for human dignity and justice } & Public & 1148 & 689.78 & 791871 & -4.001 & $.000^{*}$ \\
& Private & 273 & 800.22 & 218460 & & \\
\multirow{2}{*}{ Reflective interaction } & Public & 1148 & 683.39 & 784526.5 & -5.211 & $.000^{*}$ \\
\hline
\end{tabular}

$* \mathrm{p}<\overline{0.05}$

When the data is distributed according to school type (public school and private school), a significant difference was found in how students rated physical education teachers' professional personality competencies $(\mathrm{p}<0.05)$.

\section{Discussion}

Among the study group's assessment of the scale items, "She/he cares that honesty and trust form the basis of our communication at school" had the highest average points. "She/he does not criticize a student who exhibits negative behaviour in front of the class" had the lowest average points. Comparable results were also obtained by Demir (2015b). The results indicate that students consider honesty and trust to be the basis for teacher-student communication. It is also apparent that students are critical of other students who act out in front of the class. In this study, participating secondary school students generally evaluated the professional personality competence of physical education teachers as "partly adequate" or "completely adequate". Studies by Demir (2015a) and Demir and Karagözoğlu (2014) achieved comparable results.

An assessment of the data reveals that the highest average points were associated with the professional personality competence subcomponents of "professional enthusiasm and dedication", which was rated as "completely adequate", while the lowest average points were associated with the subcomponent of "respect for human dignity and justice". The subcomponents of "motivational interaction", "reflective interaction" and "respect for human dignity and justice" were all evaluated as "partly adequate." With this result, it is understood that physical education teachers exhibit critical behaviours to students in front of the classroom. Similarly, other recent studies have found that the professional competence of physical education teachers was evaluated as "adequate" (Demir \& Karagözoğlu, 2014; Demir, 2015a; Demir, 2015b; Kaya, 2010; Stojanovic \& Zdravkovic, 2012). Studies that assessed the justice-related features of professional competence also similarly found that physical education teachers were rated as "adequate" (Chen, Mason, Staniszewski, Upton, \& Walley, 2012; Hust, Van-Hocke, De-Knop, \& Theeboom, 2009; Hoffman \& Sembiante, 1975). Bilici (2005) found the professional personality competence of physical education teachers working in secondary schools to be "completely adequate". In additional research conducted by Kougioumtzis, Patriksson and Strahlman 
(2011), physical education teachers evaluated themselves as "quite adequate" in terms of status and professional competence. Sandıkcı and Öncü's (2013) study also revealed that physical education teachers rated their own competence highly.

When the data is distributed by gender, significant differences are found in assessment of the "motivational interaction" subcomponents, but no others. While male students rated all subcomponents of professional personality competency as "partly adequate", female students evaluated the "motivational interaction" and "professional enthusiasm and dedication" subcomponents as "completely adequate" and evaluated the other two subcomponents as "partly adequate". These results are comparable with those of Demir and Karagözoğlu (2014) and Demir (2015a). On the other hand, in the study by Safvenbom, Haugen and Bulie (2014), female students were found to be less likely than male students to feel positively towards physical education. Studies by Ünlü (2008), Eroğlu (2011), and Sandıkc1 and Öncü (2013) found no significant differences by gender. Güllü, Güçlü and Arslan (2009), in a study on the attitudes of high school students towards physical education, did find a significant difference in results by gender, while Şişko and Demirhan (2002) and İlkim (2006) did not.

A significant difference is also found when the data is distributed by class. Among those surveyed, sixth and eighth graders evaluated the professional personality competence of their physical education teachers as "partly adequate". The seventh graders also found their teachers to be "partly adequate" on the subcomponent of "respect for human dignity and justice" but found them to be "completely adequate" on the other three subcomponents. A similar study conducted among high school students found significant differences between classes (Demir \& Karagözoğlu, 2014; Demir, 2015a). Another study also found significant differences in general attitudes towards physical education by class (Güllü, Güçlü, \& Arslan, 2009).

Finally, a significant difference can be seen in students' evaluations according to school type (state or private school), with the results favouring private schools. This is thought to be because the study sample included only one private school with sufficient sports equipment, facilities and educational staff. Other research has also concluded that students studying at private schools have more positive experiences with physical education and physical education teachers (Demir, 2015a; Demir \& Karagözoğlu, 2014; Güllü, Güçlü, \& Arslan, 2009).

\section{Conclusion}

The results indicate that honesty and trust are the basis of communication between physical education teachers and students; students' satisfaction with their teachers in this regard is seen in their responses to the question of exhibiting respect and equal treatment. On the other hand, teachers apparently criticize students excessively in front of the class; students addressed this as an issue of respect for human dignity and justice. It is also apparent that physical education teachers love their work; their professional enthusiasm and dedication were highly rated.

According to the gender of the research group at seemed to be subcomponent in motivational interaction was found but other subcomponents were not found. Thus, female students in physical education lessons than male students than male students were found to provide more and they are willing to participate.

According to the school type of the research group were found significant differences all of the subcomponents in professional personality competence. This significant differences were in favour of private schools. With this result of students attending private schools, public school students in physical education from the teachers' professional competence were shown to have more personality. Facilities owned by the private school, field tools and equipment are thought to affect this conclusion.

The research group was found significant difference all of the subcomponents in professional personality competence by class. The class of 6th, 7th, and 8th among the causes of the differences obtaining between classes; the entering classes of different teachers have formal roles and participation of the physical education teachers, school students are thought to be non-active participation in sporting events.

Physical education teachers was exhibited not act fair and critical behaviours to students in front of the classroom. This psychological and pedagogical problems of student behavior (personality development problems, self-confidence problems, prevent creativity, aggressive behavior, loss of interest in the course) will be cause to emerge. This problems of physical education teachers to overcome their communication skills, assessment and evaluation, will be given appropriate training in classroom management issues faced in certain periods is recommended.

\section{Acknowledgements}

This study was presented as a proceeding at the V. European Conference on Social and Behavioral Sciences.

\section{References}

Atencio, M., Jess, M., \& Dewar, K. (2012). It is a case of changing your thought processes, the way you actually teach: 
Implementing a complex professional learning agenda in Scottish physical education. Physical Education and Sport Pedagogy, 17(2), 127-144. http://dx.doi.org/10.1080/17408989.2011.565469

Bilici, M. (2005). Okul yöneticilerinin ideal beden eğitimi öğretmenlerinden beklenti ve değerlendirilmelerinin araştırılması: Sakarya Örneği. Yayımlanmamış Yüksek Lisans Tezi, Sakarya Universitesi, Sakarya.

Büyüknacar, C. (2008). Anadolu ve fen lisesi öğretmenlerinin mesleki kişilik özellikleri ve duygusal yeterlilikleri arasındaki iliş̧kinin ögrrenci algllarına dayalı olarak incelenmesi: Gaziantep il örneği. Yayımlanmamış Yüksek Lisans Tezi, Gaziantep Universitesi, Gaziantep.

Çamlıca, C. (2008). Orta öğretim okullarında okuyan öğrencilerin beden eğitimi dersi hakkındaki düşünceleri ve beklentileri: Ankara örneği. Yayımlanmamış Yüksek Lisans Tezi, Selçuk Universitesi, Konya.

Centra, J. A., \& Potteer, D. A. (1980). School and teacher effect: an international model. Review of Education Research, 50(2), 273-291. http://dx.doi.org/10.3102/00346543050002273

Chen, W., Mason, S., Staniszewski, C., Upton, A., \& Valley, M. (2012). Assesing the quality of teacher teaching practise. Educational Assessment, Evaluation and Accountabilty, 24, 25-41. http://dx.doi.org/10.1007/s11092-011-9134-2

Darling-Hammond, L. (1999). Teacher quality and student achievement: a review of state policy evidence. Washington: Stanford University.

Demir, E. (2012). Ortaokullarda görev yapan beden eğitimi öğretmenlerinin mesleki kişilik yeterliklerinin algllanışının değerlendirilmesi. Yayımlanmamış Doktora Tezi, Marmara Universitesi, İstanbul.

Demir, E. (2015a). Students' evaluation of professional personality competencies of physical education teachers working in high schools. US-China Education Review A, 5(2), 149-157. 10.17265/2161-623X/2015.02.008

Demir, E. (2015b). Assesment of professional personality competence of physical education teachers working in çanakkale. Pamukkale Journal of Sport Sciences, 6(2), 17-32.

Demir, E., \& Karagözoğlu, C. (2014). Perceive in middle school physical education teacher of the occupational personality assesment of competencies. The Journal of Academic Social Science, 2(2), 318-328. http://dx.doi.org/10. 16992/ASOS.181

Demirhan, G., Coşkun, H., \& Altay, F. (2002). Beden eğitimi öğretmenlerinin niteliklerine ilişkin görüşler. Eğitim ve Bilim, 27(123), 35-41.

Eken, D. (2008). İlköğretim II. kademe ögrencilerinin beden eğitimi dersi hakkindaki düşünceleri ve beklentileri. Yayımlanmamış Yüksek Lisans Tezi, Selcuk Universitesi, Konya.

Eroğlu, B. (2011). Öğretmenlik uygulamasının beden eğitimi öğretmeni adaylarının mesleki yeterlikleri ve mesleğe yönelik tutumları üzerine etkileri. Yayımlanmamış Doktora Tezi, Gazi Universitesi, Ankara.

Güllü, M., Güçlü, M., \& Arslan, C. (2009). Ortaöğretim öğrencilerinin beden eğitimi dersine ilişkin tutumlarının incelenmesi. e-Journal of New World Sciences Academy, 4(4), 273-288.

Hoffman, S. J., \& Sembiante, J. L. (1975). Experience and imagery in movement analysis. In G.J.K. Alderson \& D.A. Tyldesley (Eds.), British proceedings of sports psychology (pp. 288-293). Salford, England: British Society of Sports Psychology.

Hust, K., Van Hoecke, J., De Knop, P., \& Theeboom, M. (2009). Preliminary analys of the (Process and product) quality of physical education in Flemish secondary schools: İmplemantation of IKLO. US-China Education Review, 6(7), 445-460.

Ilkim, M. (2006). Beden eğitimi öğretmenlerinin çalı̧̧ma şartlarına göre beden eğitimi dersini nasıl işlediklerinin değerlendirilmesi. Yayımlanmamış Yüksek Lisans Tezi, İnönü Universitesi, Malatya.

Karasar, N. (2011). Bilimsel araştırma yöntemleri. Ankara: Nobel Yayıncılık.

Kaya, K. (2010). Beden eğitimi ögrretmenlerinin mesleki yeterlik algıları. Yayımlanmamış Yüksek Lisans Tezi, Gazi Universitesi, Ankara.

Kougioumtzis, K., Patriksson, G., \& Strahlman, O. (2011). Physical education teachers' professionalization: A review of occupational power and professional control.European Physical Education Review, 17(1), 111-129. http://dx.doi.org/10.1177/1356336X11402266

Lee, V. E., Robinson, S. R., \& Sebastian, J. (2012). The quality of instruction in urban high schools comparing mathematics and science to english and social studies in Chicago. The High School Journal, 95(3), 14-48. http://dx.doi.org/10.1353/hsj.2012.0006 
McNeil, J. D. (1985). Cirriculum: A comprehensive introduction. Third Edition. Boston: Little, Brown and Company.

Monk, D. H. (1994). Subject matter preparetion of secondary mathematics and science teachers and student achivement. Economics of Education Review, 13(2), 125-145. http://dx.doi.org/10.1016/0272-7757(94)90003-5

Pill, S. (2004). Quality learning in physical education. Active \& Healthy Magazine, 11(3), 13-14.

Sacl, F., Bulca, Y., Demirhan, G., \& Kangalgil, M. (2009). Personal qualities of physical education teachers. Hacettepe Spor Bilimleri Dergisi, 20(4), 145-151.

Safvenbom, R., Haugen, T., \& Bulie, M. (2014). Attitudes toward and motivation for PE. Who Collects the Benefits of The Subject? Physical Education and Sport Pedagogy. http://dx.doi. org/10.1080/17408989.2014.892063

Sandıkcı, M., \& Öncü, E. (2013). Determination and comparison of physical education and the other pre-service teachers' self-efficacy beliefs and attitudes toward teaching profession. Pamukkale Journal of Sport Sciences, 4(1), $135-151$.

Şişko, M., \& Demirhan, G. (2002). İlköğretim okulları ve liselerde öğrenim gören kız ve erkek öğrencilerin beden eğitimi ve spor dersine ilişkin tutumları. Hacettepe Universitesi Eğitim Fakültesi Dergisi, 23, 205-210.

Stojanovic, S., \& Zdravkovic, D. (2012). The self-assessment of personal competences of phsical education teachers. Facta Universitatis Physical Education and Sport, 10(2), 141-149.

Stronge, J. H. (2007). Qualities of Effective Teachers. USA: Alexandria, VA ASCD.

Tannehil, D., \& Zekrajsek, D. (1993). Student attitudes toward physical education: a multicultural study. Journal of Teaching Physical Education. 13, 78- 84.

TED (2009). Öğretmen yeterlikleri. Ankara: Adım Okan Matbaacılık.

Ünlü, H. (2008). Beden ĕgitimi öğretmenlerinin yeterlikleri ve sınıf yönetim davranışları. Yayımlanmamış Doktora Tezi, Gazi Universitesi, Ankara.

Ünlü, H., Sünbül, M. A., \& Aydos, L. (2008). Beden eğitimi öğretmenleri yeterlilik ölçeği geçerlilik ve güvenirlik çalışması. Ahi Evren Universitesi Kırşehir Eğitim Fakültesi Dergisi, 9(2), 23-33.

Yaylacı, F. (2012). Beden eğitimi dersinde nitelik geliştirme sorunu. Bilim ve Aklın Aydınlı̆̆ında Eğitim, 13(147), 23-28.

\section{$(\mathrm{cc}) \mathrm{Br}$}

This work is licensed under a Creative Commons Attribution 3.0 License. 